\title{
ネパール国における区域麻酔事情
}

\section{鈴木敏之 ${ }^{* 1,2}$ 戸部 $\quad$ 賢*3 伊藤雅之 $^{* 1,2}$ 齋藤 $\quad$ 繁*3}

[要旨］ネパールにおいて，全身麻醉は非常に高価であり，使った薬剤は基本的にすべて患者負担 となる. また，使用可能な薬剤や器具は限定的である. 交通外傷が非常に多く，安価な区域麻酔は 日本以上に需要が高い。しかし，ブロックに使われる超音波装置は解像度が良好ではなく，神経刺 激装置もあるが, 電気刺激用ブロック針を購入できる患者のみに使用は限られる. 脊髄くも膜下麻 酔に使われる麻酔薬は基本的に 0.5\%高比重ブピバカインのみで, 硬膜外麻酔を含めほぼ全例座位 で穿刺が行われている. 硬膜外麻酔にはブピバカインを, 腕神経叢ブロックには $0.5 \%$ ブピバカイ ンと 10万倍アドレナリン添加2\%リドカインを混合して使うのが一般的である.

キーワード : ネパール, 区域麻酔, 局所麻酔薬, 神経ブロック

\section{はじめに}

ネパールは日本から飛行機でおよそ9時間，直行 便はなく経由地やトランジットの時間によりさらに 時間を要し, 日本からの交通の便は決して良いとは 言えない国である. 宗教は主にヒンドゥー教徒 $(81.3$ $\%)$ ，仏教徒 $(9.0 \%)$ ，イスラム教徒 $(4.4 \%)$ であり， 通貨はネパール・ルピーで1Rp は約 1 円である。ネ パール語で食事のことを「カナ」というが，カナは ダルバートという日本の定食のようなもので，朝と 晚, 1 日 2 食が基本である. その内容は豆のスープ(ダ ル)とご飯(バート), 野菜のカレーにつけあわせ (夕 ルカリ), 漬物(アチャール)が基本で, 時々お肉の カレーが出る. そしてさらに, カナとカナの合間に ちょこちょことネパール語で「カジャ」と呼ばれる 軽食(おやつ)を数回食べる。実は夕゙ルバート以外は すべてカジャで，ネパール式やきそば(チョウメン)
やうどん(タントゥク，トゥクパ)，ネパール式餃子 (モモ)，インスタントラーメン(チャウチャウ)，ネ パール式パンケーキ(ロティ)，スパゲティ，フライ ドチキン，ビスケットなどが含まれ，ネパール人に とってカジャは決してカナではない. あるネパール 人が日本に初めてきたとき，朝食にパン，昼食にス パゲテイをごちそうされ，いつになったら食事が出 てくるのかと不満を言ったという笑い話があるのは 納得できる。

ネパールは，面積 14.7 万平方キロメートル(北海 道の約 1.8 倍)，人口 2,930 万人の国で，その中に麻 酔科医は 300 人ほどしかおらず，人口 10 万人当た りの麻酔科医は 1 人である。一方，日本は人口 10 万人当たり 5 人, 米国は 13 人, ドイツは 15 人である. 米国には麻酔看護師が存在しているので，米国では 実質的な数はさらに多くなることになる，日本も麻 酔科医不足といわれるが，ネパールは日本以上に麻
*1 会津中央病院外傷再建センター

*2 福島県立医科大学外傷再建学講座

*3群馬大学大学院医学系研究科 脳神経病態制御学講座麻酔神経科学
受付日 2019. 9. 13. 受理日(採択日) 2019.12.3.
著者連絡先 鈴木敏之

产370-0001 群馬県高崎市中尾町 886 医療法人社団日高会日高病院 
表 1 薬価表 $(1 R p \doteqdot 1$ 円 $)$

\begin{tabular}{|c|c|c|c|c|c|}
\hline 薬剤 & 規格 & 薬価 (Rp) & 薬剂 & 規格 & 薬価 (Rp) \\
\hline アトラクリウム & $25 \mathrm{mg}$ & 136.25 & 10万倍アドレナリン添加 $2 \%$ リドカイン & $30 \mathrm{~mL}$ & 26 \\
\hline 0.5\%ブピバカイン & $20 \mathrm{~mL}$ & 81.95 & ミダゾラム & $25 \mathrm{mg}$ & 29.95 \\
\hline 高比重 0.5\% ブピバカイン & $4 \mathrm{~mL}$ & 40 & パラセタモール & $1000 \mathrm{mg}$ & 290 \\
\hline シサトラクリウム & $10 \mathrm{mg}$ & 407 & ペチジン & $50 \mathrm{mg}$ & 120 \\
\hline デクスメデトミジン & $100 \mu \mathrm{g}$ & 510.17 & プロポフォール & $200 \mathrm{mg}$ & $200 \sim 286$ \\
\hline ジアゼパム & $10 \mathrm{mg}$ & 35 & ロクロニウム & $50 \mathrm{mg}$ & 302.5 \\
\hline フェンタニル & $0.1 \mathrm{mg}$ & 75 & 0.5\%ロピバカイン & $10 \mathrm{~mL}$ & 77 \\
\hline イソフルラン & $250 \mathrm{~mL}$ & 2430 & セボフルラン & $250 \mathrm{~mL}$ & 6999 \\
\hline ケタミン & $100 \mathrm{mg}$ & 20.75 & サクシニルコリン & $500 \mathrm{mg}$ & 47.6 \\
\hline 2\%リドカイン & $30 \mathrm{~mL}$ & 50 & ベクロニウム & $4 \mathrm{mg}$ & 114 \\
\hline 2\%リドカイン & $50 \mathrm{~mL}$ & 51.2 & ベクロニウム & $10 \mathrm{mg}$ & 207.5 \\
\hline
\end{tabular}

酔科医不足が深刻である。ネパールの言語はネパー ル語であるが，ネパール語の医学書はなくすべて英 語である。医学を志す者はまず英語を理解すること から始まるため, 当然すべての医師は英語が堪能で ある、そんなネパールにおける区域麻酔の役割と麻 酔全般の現状調査を Manmohan Cardiothoracic Vascular \& Transplant Centre, Tribhuvan University Teaching Hospital, MEDICITY, Annapurna Neurological Institute \& Allied Sciences, Patan Hospital, B\&B Hospital, Grande International Hospital, Hospital and Rehabilitation Centre for Disabled Children, National Trauma Centerの合計 9 施設に おいて 2019年 2 月 14 日〜 3 月 17 日までカトマンズ に滞在し行ったので報告する.

\section{I 活動調査報告}

\section{1. ネパールにおける医療材料の供給とコスト負担}

ネパールの薬剤の 7 ～割はインドから輸入され る薬剤であり，残りがネパールで製造されている. しかし月の平均所得が約 3.5 万円のネパールにおい て，全身麻酔は非常に高価である。特に吸入麻酔薬 に関してセボフルランはイソフルランのおよそ 3 倍 の 7,000Rp/250mL と高価である(表 1)ためイソフル ランを主に使用しているが，一部ではいまだにハロ
タンが使われている，亜酸化窒素は，以前使用可能 であったが現在はほとんど供給されていない。基本 的に受診料は前払いであり，使った薬剤はすべて患 者負担となる，時には，患者が薬局で麻酔に必要な 薬剤を買って持参することさえある。しかし，支払 い能力があってもデスフルラン，スガマデクス，レ ミフェンタニル，レボブピバカインは入手不能であ り，マックグラス，エアウェイスコープなどのビデ オ喉頭鏡はネパールに存在しない.

\section{2. ネパールにおける区域麻酔の概要}

ネパールはオートバイ事故による四肢外傷が非常 に多く，このような国における区域麻酔は安全で安 価であり，日本以上に需要が高い。下肢は脊髄くも 膜下麻酔，長時間の効果が必要なときは脊髄くも膜 下麻酔と硬膜外麻酔の併用，上肢は超音波ガイド下 の腕神経叢ブロックが選択されている。超音波装置 も少し古く(SonoSite Mシリーズ, Mindray M5, SonoScape E2，VINNO 5，SAMSUNG製機種不明 など)解像度は良好とは言えない。神経刺激装置も 併用はできるが，電気刺激用ブロック針を購入でき る患者のみ使用可能であり，電気刺激用ブロック針 を再滅菌して使用する施設も存在する。脊髄くも膜 下麻酔は $0.5 \%$ 高比重ブピバカインを使用し, 等比 重ブピバカインは存在しない。等比重液による脊髄 


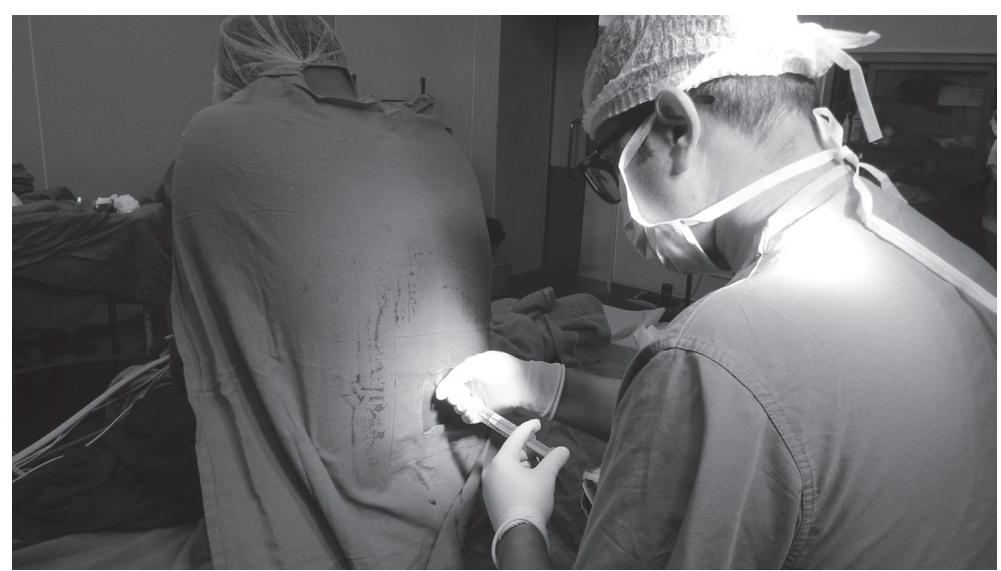

図1 硬膜外麻酔

くも膜下麻酔を行う際は硬膜外麻酔で使う $0.5 \%$ ブ ピバカインを使うか, まれに $0.75 \%$ ロピバカインを 使用する。ただしほぼ全例座位で穿刺(図1)が行わ れるので等比重液の使用はまれである。硬膜外麻酔 ではブピバカインが使われることが多く，持続注入 にはディスポーザブルのインフューザーなどはない ためシリンジポンプを使用している.

末梢神経ブロックには $0.5 \%$ ブピバカインと 10 万 倍アドレナリン添加 $2 \%$ リドカインを混合して使う のが一般的である。例えば腕神経叢ブロックはエコ ーガイド下の鎖骨上アプローチがよく選択され，滅 菌シースと滅菌ゼリーを使用できるところもあった が，滅菌手袋と生理食塩水でよく代用されていた。

以下に代表として，ネパールで最初の国立大学で あるトリブバン大学(1959年設立) 附属病院である Tribhuvan University Teaching Hospital(表2) と数 年前に Teaching Hospital から専門病院として独立 した Manmohan Cardiothoracic Vascular \& Transplant Centre(表3)の状況を詳しく紹介する．Manmohan Cardiothoracic Vascular \& Transplant Centreはトリブバン大学麻酔科教授かつネパール 麻酔科学会会長である Prof. Bishwas Pradhanの所 属する病院である。

\section{1)医師の待遇と診療費}

ネパールの国立大学の医師の給与は月平均約 12
万円，大学講師は約 7 万円(所得税は $15 \%$ )。一方, 患者は受診開始前に診察料を約 60 円支払う。CT撮 影は 6,000〜7,000円である. 前の症例が伸びると外 科医と麻醉科医が相談の上, 容易に次の症例はキャ ンセルとなるため必ず手術は時間内に終わる.また， 外来手術などの場合，患者数が相当多いためかなり 処置日が先になることが多いが，追加金を払うと PM4 時以降に順番を飛ばして早く処置するシステ ムがある。

2)腕神経叢ブロックまたは末梢神経ブロック

腕神経叢ブロックは，Manmohan Cardiothoracic Vascular \& Transplant Centreでは主に透析用のシ ヤント手術に対して行われ，10万倍アドレナリン 添加 $2 \%$ リドカイン $0.175 \mathrm{~mL} / \mathrm{kg}(\operatorname{Max} 0.35 \mathrm{~mL} / \mathrm{kg})$ $+0.5 \%$ ブピバカイン $0.03 \mathrm{~mL} / \mathrm{kg}(\operatorname{Max} 0.04 \sim 0.06 \mathrm{mg})$ $\mathrm{kg}$ ) 混合液を使用する。一方 Teaching Hospital で は，腕神経叢ブロックに $0.25 \sim 0.5 \%$ ロピバカイン 15〜20mLが主に使用される。また，腹横筋膜面ブ ロックには $0.1 〜 0.2 \%$ ロピバカイン $10 \mathrm{~mL}$ ，閉鎖神 経ブロックには $0.75 \%$ ロピバカインや $0.5 \%$ ブピバ カイン $20 \mathrm{~mL}$ が主に使用される。

3) 春髄くも膜下麻酔

目標行為に応じて $0.5 \%$ 高比重ブピバカインを以 下のように投与している; Th4 = 3.5〜 4mL，Th7 $=3 \sim 3.5 \mathrm{~mL}, \quad \mathrm{Th} 10=2.5 \mathrm{~mL}$. 脊髄くも膜下麻酔が 
表2 Tribhuvan University Teaching Hospital の手術室の状況 (2016-2017)

\begin{tabular}{|c|c|c|c|c|}
\hline 専門 & \multicolumn{4}{|c|}{ 心臓血管胸部を除く全般 } \\
\hline 病床数 (床) & \multicolumn{2}{|l|}{663} & & \\
\hline 手術室数 (屋) & \multicolumn{2}{|l|}{11} & & \\
\hline \multirow[t]{2}{*}{ 麻酔科医数 (人) } & 常勤 14 & 非常勤 6 & レジデント 9 & \\
\hline & & 定時 & 緊急 & 合計 \\
\hline \multirow[t]{18}{*}{ 手術件数 (件) } & 消化器外科 & 768 & 735 & 1,503 \\
\hline & 整形外科 & 1,172 & 782 & 1,954 \\
\hline & 耳鼻科 & 1,961 & 191 & 2,152 \\
\hline & 眼科 & 70 & 56 & 126 \\
\hline & 婦人科 & 943 & 271 & 1,214 \\
\hline & 産科 & - & - & 2,048 \\
\hline & 形成外科 & 720 & 233 & 953 \\
\hline & 脳外科 & 276 & 292 & 568 \\
\hline & 泌尿器科 & 1,462 & 84 & 1,546 \\
\hline & 皮膚科 & - & - & 1,666 \\
\hline & 腎移植 & 66 & 0 & 66 \\
\hline & 乳腺甲状腺外科 & 152 & 0 & 152 \\
\hline & 小児外科 & 252 & 65 & 317 \\
\hline & 歯科口腔外科 & 32 & 2 & 34 \\
\hline & ペイン & 57 & 10 & 67 \\
\hline & ECT & - & - & 43 \\
\hline & その他 & 33 & 84 & 117 \\
\hline & 合計 & & & 14,526 \\
\hline
\end{tabular}

座位で行われ高比重ブピバカインを投与するため, 本邦より多く投与される傾向があると考える。帝王 切開に際しては，0.5\%高比重ブピバカインを，身長 $150 \mathrm{~cm}$ 以下では $2.2 \mathrm{~mL} ，$ 身長 $150 \mathrm{~cm}$ 以上では $2.4 \mathrm{~mL}$ 使用する。

\section{4) 硬膜外麻酔}

硬膜外カテーテルの固定はTuohy 針で皮下トン ネルを作ってから固定している. 留置後にテスト量 は 10 万倍アドレナリン添加 $2 \%$ リドカインを使用し ていた。高侵襲手術では通常, 硬膜外麻酔または脊 髄くも膜下モルヒネ投与 $(100 \sim 200 \mu \mathrm{g})$ に全身麻酔 を併用して行われている。

麻酔目的としては $0.25 〜 0.5 \%$ ブピバカインを主 に使用し，術後の鎮痛目的としては $0.08 〜 0.1 \%$ ブ
ピバカインまたは $0.1 〜 0.2 \%$ ロピバカインが主に使 用される。例えば術後持続硬膜外鎮痛では $0.2 \%$ ロピ バカイン $50 \mathrm{~mL}+$ フェンタニル $100 \mu \mathrm{g}$ を 2 5mL/h が一般的である。

\section{5) 全身麻酔}

麻酔導入は，プロポフォールおよびベクロニウム を用い，健忘作用を得るためミダゾラムを併用して いる。麻酔維持はイソフルランとモルヒネまたはフ エンタニルを使用するが，フェンタニルの供給が少 ないため，長時間手術ではモルヒネを優先して使用 する。セボフルランの使用は小児の麻酔導入時など に限られている。約 1 年前までは八ロタンが使用さ れていたとのことである。なおこの施設では余剩が ス廃棄システムが設置されている部屋は 1 室のみで 
表3 Manmohan Cardiothoracic Vascular \& Transplant Centre の状況 (2017-2018)

\begin{tabular}{|c|c|c|c|c|}
\hline 専門 & \multicolumn{4}{|c|}{ 心臓血管胸部および移植 } \\
\hline 病床数(床) & \multicolumn{2}{|c|}{94} & & \\
\hline 看護師数 (人) & \multicolumn{2}{|l|}{164} & & \\
\hline \multirow[t]{3}{*}{ 医師数 (人) } & 麻酔科医 & 常勤 6 & 非常勤 2 & レジデント 3 \\
\hline & 循環器内科医 & 常勤 9 & 非常勤 0 & レジデント 8 \\
\hline & 心臓血管外科医 & 常勤 10 & 非常勤 0 & レジデント 3 \\
\hline 手術室数 (室) & \multicolumn{2}{|l|}{3} & & \\
\hline \multirow[t]{9}{*}{ 手術件数 (件) } & 1320 & & & \\
\hline & \multirow[t]{5}{*}{ 内訳 } & 血管外科 & $48 \%$ & \\
\hline & & 心臓外科 & $34 \%$ & \\
\hline & & 胸部外科 & $17 \%$ & \\
\hline & & 移植外科 & $0 \%$ & \\
\hline & & その他 & $1 \%$ & \\
\hline & \multirow[t]{3}{*}{ 麻酔内訳 } & 全身麻酔 & $78 \%$ & \\
\hline & & 区域麻酔 & $7 \%$ & \\
\hline & & 局所麻酔 & $15 \%$ & \\
\hline
\end{tabular}

あるため, 通常導入直後から吸入麻酔薬は流さず, 挿管後から投与を開始し, 維持は低流量麻酔で行う。 また, たびたび吸入麻酔を投与し忘れることがあり， ドルミカム併用が重要となってくると感じた.また, 挿管後の循環変動を抑える目的で，麻酔導入時にリ ドカインの静注をすることがある。鼻の手術に際し ての全身麻酔では, 術中の低血圧維持, 覚醒時興奮 の予防目的にデクスメデトミジンの併用を推奨して いた。ケタミンは広く使用されており，Pre-emptive analgesia として $0.25 〜 0.5 \mathrm{mg} / \mathrm{kg}$ を執刀 $5 \sim 10$ 分前 に投与していた。

6)その他の薬剤および手術環境

代表的な循環作動薬として，ミルリノンの導入で 10 分程度の緩徐な投与は行わず， $3 \mathrm{mg}$ ボーラス投 与後, $0.5 \mu \mathrm{g} / \mathrm{kg} / \mathrm{min}$ の持続投与へと移行する.心 房細動のレートコントロールにはアミオダロン $300 \mathrm{mg}$ を静脈内投与する。喉頭痙攣に対してはニ トログリセリンを使用する。腎移植も行われており, ドナーはマンニトール，レシピエントはハイドロコ ルチゾン $100 \mathrm{mg}+$ 抗胸腺細胞グロブリン $50 \mathrm{mg}$ をル
ーティンとして使用していた。

経皮的心肺補助法(PCPS), 大動脈内バルーンパ ンピング法(IABP)，セルセーバーを用いた回収式 自己血輸血法は配備されており，MEの管理のもと 消耗品も十分供給されている.

7)不十分な手術室設備と衛生管理

停電により一日一度は真っ暗になり, UPS(無停 電電源装置)らしきもの(図2) はあるがモニターも 麻酔器もなぜかすべて電源が落ちることがあった。 術後写真は撮らない。カプノメーターはあるが吸入 麻酔ガスモニターやBIS はない，亜酸化窒素が中央 配管から供給されるがすべての部屋にあるわけでは ない．中央配管による圧縮空気はほとんど供給され ていないことが多く，供給されても使用開始後すぐ になくなるため，基本的に全身麻酔はほぼ純酸素で 行う。手術室内へ患者は裸足で歩いて入室する (図3). 日本と違って脊髄くも膜下麻酔の前には手 洗いをし，滅菌がウンを着用し施行する。この施設 の手洗いの水は地下水をろ過し滅菌しているため, ネパールでは例外的に飲用も可能なほどきれいであ 


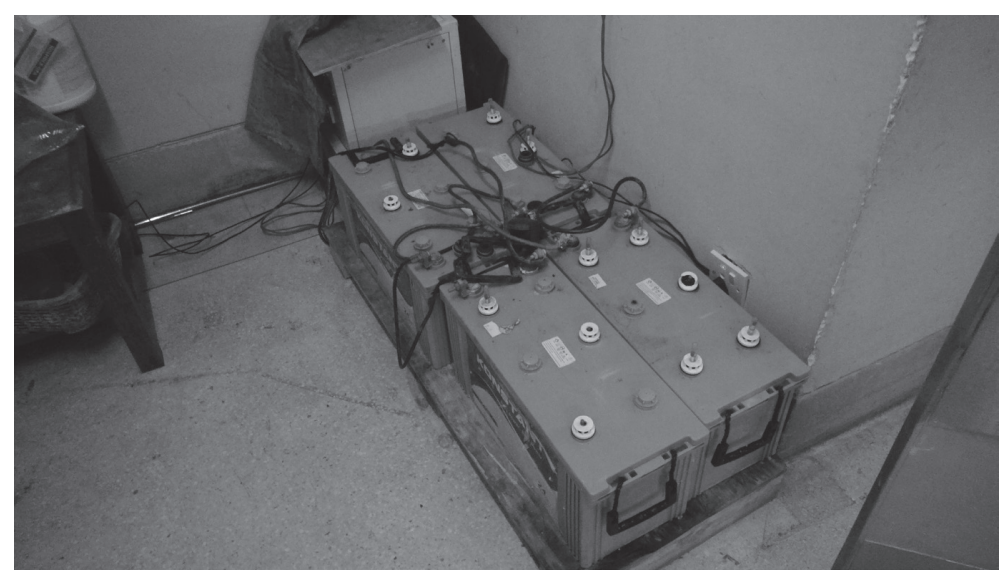

図2 無停電電源装置

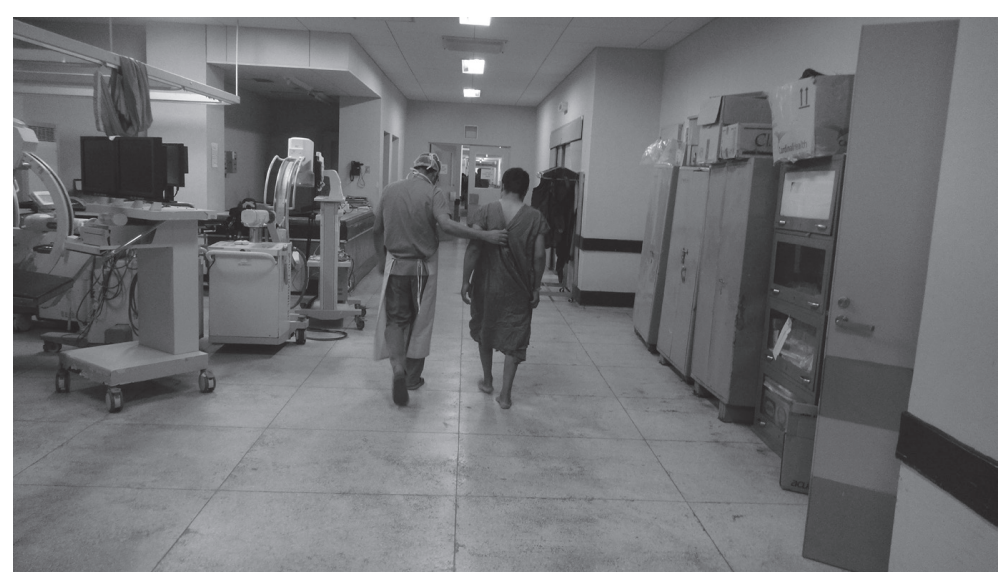

図3手術室を裸足で歩く患者

る. 泌尿器科の経尿道手術のカメラはアルコールで 消毒するのみ, 耳鼻科の副鼻腔内視鏡手術用カメラ は滅菌したものを使用するが，イントロデューサー と電動デバイスはアルコール消毒のみである，その 際のアルコールの濃度は $90 \%$ であった。側管から の投薬用のシリンジは, 感染症がなければ薬剤を含 め一日使いまわしをする。

8)経済的な事情による特殊性

本邦と違い人件費が安く医療材料の物価が高いた め, 消耗品と思われるかなりのものが再滅菌して再 利用される。しかし，ロクロニウム，デクスメデト ミジン, 電気刺激用ブロック針, 観血的動脈圧測定 回路などは病院にほとんど供給されず，使用が必要
な手術を受ける場合や使用することを患者が望む場 合には，事前に患者と相談し購入してもらい，それ を持参して手術室に入室しないといけない。一般的 なプロポフォール，ベクロニウム，ミダゾラム，フ エンタニル，モルヒネはお括むね病院から供給され ており，これらは患者が購入して持参する必要はな いが，やはり常にあるわけではなく，その場合は購 入してもらう必要がある。また，薬剤や消耗品は病 院に供給されるものを含め，製薬会社や製造会社が 常にその時に応じて変わり, 值段も一定ではない. 9)印象に残った具体的な症例

- 96 歳転子間骨折の手術で脊髄くも膜下麻酔に際 してフェンタニル $15 \mu \mathrm{g}+0.5 \%$ 高比重ブピバカ 
イン $2.5 \mathrm{~mL}$ を投与した。 上位胸椎まで麻酔レべ ルは上昇しリンゲル液の過剰輸液に加え, メフ エンタミンやフェニレフリンの反応に乏しい低 血圧が遷延したため, 肺血栓症などの鑑別診断 を行うようアドバイスした。

・当施設の臨床研究の症例として $0.75 \%$ ロピバカイ ン $3 \mathrm{~mL}$ による脊髄くも膜下麻酔が行われ, 運動 神経への影響が少なく手術が可能であった。一方, $0.75 \%$ ロピバカイン $2.8 \mathrm{~mL}+$ フンタニル $25 \mu \mathrm{g}$ をくも膜下投与した症例では, 逆に運動神経への 効果が強く, 効果発現も速い結果となった. ロピ バカインの比重は不明だがフェンタニルの相乗効 果による作用増強が示唆された。

\section{II 考察}

ネパール人医師の医学知識や技術向上への志は日 本人以上であると感じられた。ネパールと日本の麻 酔事情の差は, 知識や技術の差によるものではなく, 国家の経済状況と関連した医療資源の供給体制にあ ると考えられた。そして，ネパールの麻酔科医は非 常に少ないが，首都カトマンズに限っては医師があ る程度確保されている。これらのことから，ネパー ル支援の要点は，麻酔科医不足に対する人材支援で はなく，設備や物資などの入手ルートの確保と経済 支援と考えられた。

\title{
Regional Anesthesia in Nepal
}

\author{
Toshiyuki SUZUKI ${ }^{* 1,2}$, Masaru TOBE*3, Masayuki ITO*1,2, Shigeru SAITO*3 \\ ${ }^{* 1}$ Traumatology and Reconstructive Surgery Center, Aizu Chuo Hospital \\ ${ }^{* 2}$ Department of Traumatology and Reconstructive Surgery, Fukushima Medical University \\ ${ }^{* 3}$ Department of Anesthesiology, Gunma University Graduate School of Medicine
}

In Nepal, there are a lot of traffic injuries that require anesthesia to treat. In these cases, patients must pay the entire cost of general anesthesia. In addition, anesthesiologist have access to limited medicine and equipment. As a result, the demand for regional anesthesia is very high compared to Japan. However, ultrasonic devices that anesthesiologists use have low resolution for providing peripheral nerve block. Anesthesiologists can use neural stimulators only for patients who can purchase nerve-blocking needles made for electrostimulation. In most cases, patients must be kept in a sitting position to puncture for spinal and epidural anesthesia. Virtually the only anesthetic used for spinal anesthesia is hyperbaric $0.5 \%$ bupivacaine. Anesthesiologists generally use bupivacaine for epidural anesthesia and a mixture of $0.5 \%$ bupivacaine and $2 \%$ lidocaine with $1: 100000$ adrenaline for brachial nerve block.

Key Words : Nepal, Regional anesthesia, Local anesthetic, Nerve block

The Journal of Japan Society for Clinical Anesthesia Vol.40 No.2, 2020 